\title{
MEMBANGUN KARAKTER GURU AGAMA HINDU YANG PROFESIONAL DAN DINAMIS DALAM KERANGKA PANCASILAIS NUSANTARA (PERSPEKTIF FILSAFAT HINDU)
}

\author{
I Ketut Subagiasta \\ Institut Agama Hindu NegeriTampungPenyangPalangkaraya \\ bawiayahfda@gmail.com
}

\section{Riwayat Jurnal \\ Artikel diterima : - \\ Artikel direvisi :- \\ Artikel disetujui :-}

\begin{abstract}
Abstrak
Guru agama Hindu berperan untuk mengajarkan materi agama Hindu terkait dengan karakter luhur, karakter mulia, karakter tanggungjawab, karakter pendidikan, karakter ekonomi, karakter spiritual, karakter sosial, karakter taat hukum, karakter rajin belajar, karakter saling menolong, dan sebagainya. Guru agama Hindu dituntut untuk tekun belajar, selain tekun mengajar. Guru agama Hindu tidak bisa tanpa belajar yang tekun. Perkembangan dan kemajuan proses pendidikan peserta didik ada di tangan guru agama Hindu. Pendidikan karakter kepada para guru agama Hindu sesungguhnya upaya pembangunan di bidang nonfisik. Perlunya penyeimbangan antara pembangunan fisik dan nonfisik secara berkelanjutan sampai ke masa depan. Selain pendidikan karakter juga penting diteguhkan mengenai materi Pancasila, agar kehidupan bangsa Indonesia mencapai hidup yang sejahtera, bahagia, dan berkeadilan. Membangun nilai-nilai karakter sesuai filsafat Hindu dan sekaligus menanamkan nilai luhur Pancasila sebagai upaya positif guna menjadikan para guru agama Hindu sebagai pelopor dan pengabdi yang akan melahirkan generasi Hindu yang berkualitas, bertanggungjawab, dan memiliki ketahanan mental, moral spiritual, dan kepribadian yang mantap. Pendidikan karakter sesuai filsafat Hindu dimaksudkan untuk membangun kecintaan, ketulusan, kesetiaan, dan kesinambungan dedikasi dan loyalitas umat Hindu kepada agama Hindu sekaligus juga loyalitas kepada bangsa dan Negara Kesatuan Republik Indonesia.
\end{abstract}

Kata Kunci: Membangun Karakter, Guru Agama Hindu, Kerangka Pancasilais

\section{PENDAHULUAN}

Pembangunan bangsa Indonesia dewasa ini yang dilaksanakan oleh pemerintah Republik Indonesia merupakan pembangunan yang bersifat multi target. Maknanya adalah pembangunan yang dilakaakan secara utuh, yakni pembangunan di bidang spiritual dan pembangunan di bidang material. Dengan kata lain bahwa 
pembangunan yang dilaksanakan merupakan pembanguna nonfisik dan pembangunan fisik. Kedua jenis pembangunan yang ditargetkan tersebut wajib diseimbangkan dan wajib diharmoniskan. Antara pembangunan fisik dan nonfisik tidak bisa dikesampingkan begitu saja, atau antara pembangunan fisik dan nonfisik dilaksanakan secara saling ketergantungan, saling melengkapi, saling isi mengisi, saling disuburkan, saling dikembangkan, saling dipelihara dengan baik, saling diperhatikan oleh semua pihak yang peduli terhadap dinamika pembangunan bangsa Indonesia yang maju, sejahtera, dan berkeadilan.

Pelaksanaan pembangunan fisik sepertinya terkesan sangat penting, namun pembangunan nonfisik sesungguhnya juga sangat penting. Kedua objek pembangunan sesungguhnya sangat penting dan tidak bisa diabaikan begitu saja tanpa adanya upaya keseimbangan di antara kedua jenis pembangunan yang sama-sama memberikan kontribusi ataupun andil yang sama untuk mengupayakan terwujudkan kemajuan sercara berkeseimbangan dan berkeadilan. Pembangunan fisik dipacu dengan baik, maka pembangunan nonfisik pun juga diupayakan dengan baik pula. Bilamana pembangunan fisik seperti infra struktur, pembangunan gedung, pembangunan fasilitas, pembangunan berbagai sarana kepertluan bagi warga masyarakat dilakukan dengan baik, maka pembangunan nonfisik atau pembangunan spiritual juga dilakukan secara baik pula, misalnya pembainaan moral, pembinaan kerohanian, pembinaan mental, pembinaan karakter, pembinaan kepribadian manusia Indonesia, pembinaan warga Negara Indonesia menuju loyalitas, dedikasi, kepercayaan, keyakinan, kematangan dalam berpikir, dan sebagainya.

Bilamana pembangunan fisik berupa jalan raya, kantor, sekolah, kampus, pasar, perrumahan, hotel, jembatan, fasilitas angkutan, fasilitas beragama berupa tempat suci, fasilitas petani berupa pembangunan dam, dan sebagainya dilakukan dengan anggaran yang sangat besar, maka pembangunan di bidang nonfisik pun wajib dibiayaai secara proporsional. Banyak hal yang dapat diupayakan di bidang pembangunan nonfisik, misalnya : melakukan penyuluhan agama, melakukan orientasi karakter kepada para guru agama, melakukan orientasi kerohanian kepada lapisan masyarakat di desa-desa, melakukan penerangan atau pelatihan kepemangkuan, melakukan pembinaan agama kepada para generasi muda, melakukan kegiatan pembinaan spiritual kepada para wanita ataupun kepada para warga masyarakat secara menyeluruh tanpa dibeda-bedakan, sehingga segenap warga masyarakat menjadi warga yang damai, rukun, bersatu, mantap, solid, kompak, dan saling bertoleransi dalam kehidupannya di tengah masyarakat.

"Oleh karena peranan guru yang menguasai methode atau cara mengajar, selanjutnya diajarkan olehnya. Itulah sebabnya antara guru dan siswa juga 
mesti menempatkan guru sebagai suatu hal yang patut dihormati, ditaati, diikuti segala ajarannya, kalau siswa ingin keberhasilan dalam mengikuti pendidikan” (Singer, 2015 : 43). Dalam hal ini guru agama Hindu berperanan untui mengajarkan materi agama Hindu terkait dengan karakter luhur, karakter mulia, karakter tanggungjawab, karakter pendidikan, karakter ekonomi, karakter spiritual, karakter social, karakter taat hukum, karakter rajin belajar, karakter saling menolong, dan sebagainya. Guru agama Hindu dituntut untuk tekun belajar selain tekun mengajar. Guru agama Hindu tidak bisa tanpa belajar yang tekun. Perkembangan dan kemajuan proses pendidikan peserta didik ada di tangan guru agama Hindu. dengan demikian beban dan perannya sangat mulia namun kreatif.

\section{PEMBAHASAN}

\subsection{Membangun Karakter Guru Agama Hindu Perspektif Filsafat Hindu}

Berkenaan dengan membangun karakter para guru agama Hindu sesuai perspektif filsafat Hindu yang menjadi point penting dalam paparan ini, maka hal ini merupakan hal yang sangat urgen dalam upaya mewujudkan pembangunan fisik dan nonfisik bagi warga masyarakat Hindu di Indonesia. "Upaya pembangunan fisik dan nonfisik wajib diselaraskan secara berkesinambungan sepanjang masa tiada pernah berhenti. Pembangunan fisik dipengaruhi oleh pembangunan nonfisik, sebaliknya pembangunan nonfisik memberikan dampak mulia pada pembangunan fisik. Penyeimbangan antara pembangunan fisik dan nonfisik merupakan upaya kontinyu dari berbagai lapisan masyarakat bersama unsure pembina masyarakat yang selalu bersinergi" (Subagiasta, 2016 : 1). Makna pembangunan yang berkeseimbangan tersebut merupakan makna pembangunan yang berkelanjutan. Pelaksanaan pembangunan nonfisik tidak bisa dilakukan hanya sekali saja dan akhirnya berhenti begitu rupa, namun terus dilakukan dengan rutin, bagaimana memelihara tanaman, maka tanaman itu mesti disiram air, dipupuk, digemburkan tanahnya, disemprot, dipagari, dan sebagainya sehingga tanaman tersebut dapat mengahasilkan buah, bunga, daun, batang, biji, putik, getah, dan hasil lainnya yang bekualitas.

Menurut Koesoema (dalam Subagiasta, 2016 : 25) bahwa "Secara historis kata pendidikan banyak dipakai untuk mengacu pada berbagai macam pengertian, misalnya pembangunan (develpmpemnt),

pertumbuhan/perkembangan, format, sosialisasi, inkulturasi, pengajaran, pelatihan, pembaruan". Selanjutnya makna karakter dijelaskan juga menurut Koesoema (dalam Subagiasta, 2016 : 25) bahwa "mengasosiasikan istilah karakter dengan apa yang disebut degan temperamen yang memberinya sebuah definisi yang menekankan unsur psikososial yang dikaitkan dengan pendidikan dan konteks lingkungan". Menurut Subagiasta bahwa "pendidikan 
karakter adalah bentuk pendidikan yang menekankan pada kepribadian atau temperamen dari peserta didik yangmengandung unsur psikososial serta berkontektual dengan situasi lingkungan masing-masing. Jadi pendidikan karakter merupakan komponen pendidikan yang mengupayakan pembinaan pribadi atau sifat-sifat peserta didik guna mencapai kualitas sumber daya manusia yang handal dengan proses pembelajaran secara fedagogik serta sumber belajar dari lingkungan setempat seperti : agama, adat-istiadat, budaya, seni, social, ekonomi, komunikasi,informasi, dan sebagainya yang turut membentuk kepribadian mulia peserta didiksesuai jenjang pendidikannya". Dalam hal ini ditegaskan bahwa pendidikan karakter adalah pendidikan dengan upaya membangun mental, moral, spiritual, kerohanian, pribadi, dan sifat-sifat pada peserta didik yang lihur, mulia, baik, benar, taat, disiplin, jujur, dan bertanggungjawab.

"Pembicaraan

mengenai

pendidikan karakter sungguh-sungguh menarik dan patut dijadikan bahan diskusi yang tiada habisnya oleh semua pihak yang terkait untuk memberikan masukan, saran, koreksi, serta upaya memberikan sumbangan positif guna turut berpartisipasi mengembangkan secara baik pribadi-pribadi peserta didik dalam dunia pendidikan, baik dalam pendidikan dasar, menengah dan pendidikan tinggi, termasuk di dalamnya adalah pendidikan tinggi agama Hindu" (ibid, 34). Intinya bahwa pendidikan karakter oleh guru agama Hindu wajib dikembangkan terus guna membangun kualitas sumber daya manusia Hindu yang handal dan berkompetensi baik. Guru agama Hindu sebagai sumber pengembangan karakter Hindu diwajibkan untuk berdedikasi dan loyalitas baik untuk mencetak generasi muda Hindu yang baik.

Dalam paparan sederhana ini diuraikan beberapa point penting terkait dengan kegiatan orientasi guru agama Hindu, antara lain : a) materi karakter profesional dan dinamis, b) materi karakter rajin berdoa, c) materi karakter giat bekerja, d) materi karakter tekun belajar, e) materi karakter gemar menolong, f) materi karakter suka bercocok tanam, g) materi karakter berdisiplin, h) materi karakter keramahtamahan, i) materi karakter cinta damai, j) materi karakter peduli lingkungan, k) materi karakter setia kebangsaan, dan 1) materi karakter bela negara. Sesungguhnya masih banyak materi yang bekaitan dengan karakter yang dapat dipaparkan dalam konteks untuk membangunan guru agama Hindu yang professional, dinamis dan berpancasilais nusantara, yang pada intinya dapat memberikan dampak kemuliaan dan keluhuran kepribadian, sehingga mampu mengabdi dengan sebaik-baiknya untuk membanguna kader muda Hindu yang berkualitas, bertanggungjawab, berkompetensi, dan siap mkengabdi pula pada negara tercinta. Berangkat dari upaya untuk memberikan orientasi karakter kepada para guru 
agama Hindu yang bertugas di berbagai pelosok tanah air meruipakan hal yang positif dan konstruktif, yang patut dikembangkan terus secara tahun demi tahun, sehingga guru agama Hindu dapat menjadi panutan, conton, teladan, dan pelopor terbaik dalam membangun kader Hindu yang berkualitas.

\subsection{Karakter Profesional dan Dinamis}

Mengapa guru agama Hindu dituntut berkarakter professional dan dinamis? Bila dijawab pertanyaan tersebut, maka jawabannya adalah karena guru agama Hindu sebagai pelayan umat Hindu, sebagai pembina umat Hindu, sebagai penuntun umat Hindu, sebagai pencetak kader Hindu yang berkualitas, sebagai pembimbing umat Hindu yang sadar terhadap kewajibannya menjadi umat Hindu yang dipanutani oleh orangorang yang ada dalam masyarakat, dan sebagainya masih banyak lagi jawaban empiris yang sangat menyentuh serta sangat relevan dalam perannya sebagai guru agama Hindu. Demikian juga halnya bahwa guru agama Hindu wajib mengembangkan wawasannya, memgembangkan pengetahuannya, mengembangkan ideanya, mengembangkan kemampuan belajarmengajarnya, mengembangkan keterampilannya, guru agama Hindu juga diwajibkan untuk mengabdi dengan sebaik-baiknya kepada seluruh lapisan masyarakat dimanapun para guru agama Hindu bertugas dan menjalankan kewajibannya sebagai abdi masyarakat, abdi agama, abdi social, abdi bangsa, abdi negara, maupun sebagai abdi di bidang pendidikan yang bertugas mentransformasi, membangun kader Hindu professional dan dinamis pula, sehingga para kader Hindu bisa menjadi kader yang kompetitif dan sukses. Jadi guru agama Hindu memberikan kekayaan termahal berupa pengetahuan karakter ke siswa-siswi.

\subsubsection{Karakter Rajin Berdoa}

Hal yang tergolong dalam karakter rajin berdoa, sebagai berikut : 1) kepribadian yang rajin melakukan puja tri sandhya, 2) kepribadian yang rajin melakukan lagu pujian, 3) kepribadian yang rajin melakukan kidung pujaan, 4) kepribadian yang rajin melakukan bhakti kepada Ida Sang Hyang Widhi Wasa atau Ranying Hatalla Langit, 5) kepribadian yang rajin melakukan doa bhajanam, 6) kepribadian yang rajin melakukan pujaan macepat, 7) kepribadian yang rajin melakukan pujaan sloka, 8) kepribadian yang rajin melakukan pujaan wiramal kakawin, 9) kepribadian yang rajin melakukan pujaan phalawakya, 10) kepribadian yang rajin melakukan pujaan kandayu, 11) kepribadian yang rajin melakukan pujaan kerohanian, 12) kepribadian yang rajin melakukan pujaan spiritual, 13) kepribadian yang rajin melakukan puja bhakti, 14) kepribadian yang rajin melakukan tuntunan batin, 15) kepribadian yang rajin melakukan saha, sasontengan, manandak, maupun puja sesuai desa kala patra, 16) kepribadian yang rajin melakukan puja Samadhi, 17) kepribadian yang rajin melakukan puja mona brata, 18) kepribadian yang rajin melakukan japa mantra, dan sebagainya 
yang sangat positif untuk dapat membangun, membangkitkan karakter untuk rajin berdoa secara keseharian dan waktu tertentu.

\subsubsection{Karakter Giat Bekerja}

Dalam hal karakter giat bekerja patut diperhatikan oleh para guru agama Hindu, antara lain : 1) giat bekerja sesuai kebenaran (dharma), 2) giat bekerja sesuai disiplin (yama-nyama brata), 3) giat bekerja sesuai kebijaksanaan (gunamantha), 4) giat bekerja sesuai ketulusan (lascarya), 5) giat bekerja sesuai kesucian (nirmala), 6) giat bekerja sesuai kelembutan (sadhu), 7) giat bekerja sesuai pengabdian (bhakti), 8) giat bekerja sesuai kecerdasan (budhi), 9) giat bekerja sesuai keterampilan (abhyasa), 10) giat bekerja sesuai kepribadian (gunadharma), 11) giat bekerja mencapai kesejahtraan bersama (sarwa hita), 12) giat bekerja mencapai kebahagiaan bersama (sarwa bhagya), 13) giat bekerja dengan kerja professional (subhakarma), 14) giat bekerja dengan ulet atau tekun kebenaran (karmani), 15) giat bekerja sesuai cinta kasih (paramita), 16) giat bekerja tanpa kekerasan (ahimsa), 17) giat bekerja sesuai tanpa korupsi (acorah karma), 18) giat bekerja tanpa kesalahan (adosha), 19) giat bekerja tanpa ketamakan (alobha), 20) giat bekerja tanpa kemarahan (akrodha), 21) giat bekerja tanpa keangkuhan (ahamkara karma), dan masih banyak lagi terkait karakter giat bekerja yang dapat dilakukan secara pemahaman maup secara praktek langsung, guna membangun probadi yang luhur dan bijaksana yakni sadhu gunawan. Karakter giat bekerja merupakan pribadi sejati yang sangat mengutamakan kerja berkualitas dan bukan mengutamakan hasilnya terlebih dahulu.

\subsubsection{Karakter Tekun Belajar}

Karakter tekun belajar merupakan masa belajar atau brahmacari. Karakter tekun belajar merupakan kewajiban mulia bagi sadharma, yakni : 1) karakter tekun belajar tentang agama Hindu (dharma), 2) karakter tekun belajar tentang ekonomi (artha sastra), 3) karakter tekun belajar tentang lagu agama Hindu (dharmagita atau samaveda), 4) karakter tekun belajar tentang doa pujaan (rgveda), 5) karakter tekun belajar tentang persembahan (yajurveda), 6) karakter tekun belajar tentang pertanian (warta), 7) karakter tekun belajar tentang kesehatan (ayurveda), 8) karakter tekun belajar tentang kesenian (gandharwaveda), 9) karakter tekun belajar tentang kebudayaan (sanskriti), 10) karakter tekun belajar tentang seni tari (natya), 11) karakter tekun belajar tentang obat-obatan (tamba), 12) karakter tekun belajar tentang ketentuan hari baik (subhadewasa atau wariga), 13) karakter tekun belajar tentang perbintangan (jyotisa), 14) karakter tekun belajar tentang politik Hindu (dandhaniti), 15) karakter tekun belajar tentang kepemimpinan (nitisastra), 16) karakter tekun belajar tentang spiritual (paravidya), 17) karakter tekun belajar tentang ilmu pengetahuan teknologi (aparavidya), 18) karakter tekun belajar tentang kesusastraan (susastra), 19) karakter tekun belajar 
tentang hukum (vidhi sangkhaya atau dharma sastra), 20) karakter tekun belajar tentang filsafat (darsanam), 21) karakter tekun belajar tentang komunikasi (dharmaduta), 22) karakter tekun belajar tentang ketuhanan (brahmavidya), 23) karakter tekun belajar tentang orang suci (pandita ca pinandita), dan sebagainya yang penting dipejari dengan dasar untuk membangun jati diri yang professional dan dinamis.

\subsubsection{Karakter Gemar Menolong}

Kehidupan manusia di alam semesta tidak bisa tanpa bantuan dan pertolongan orang lain di sekitar kehidupan dalam kebersamaan yang penuh denga keragaman (kebhinekaan). Karakter gemar menolong penting dibangun oleh siapapun menuju kebersamaan, yakni : 1) karakter gemar menolong orang sakit (janman asvasthya), 2) karakter gemar menolong orang sengsara (janman samsara), 3) karakter gemar menolong orang sedih (janman duhkha), 4) karakter gemar menolong orang kematian (janman mrtyu), 5) karakter gemar menolong orang melarat (janman hina), 6) karakter gemar menolong orang cacat (janman marana), 7) karakter gemar menolong orang tua (janman wrdha), 8) karakter gemar menolong orang buta (tuna netra), 9) karakter gemar menolong orang gelandangan (janman tuna grahita), 10) karakter gemar menolong orang yatim piatu (nahi mata pita), 11) karakter gemar menolong orang yang diperkosa (paradara), 12) karakter gemar menolong orang miskin (daridra), 13) karakter gemar menolong orang kelaparan (janman nahi bhoga), 14) karakter gemar menolong orang compang-camping (janmannahi wastra), 15) karakter gemar menolong orang gila (janman moha), 16) karakter gemar menolong orang melahirkan (janman garbhata), 17) karakter gemar menolong orang kecil (janman sisu), 18) karakter gemar menolong orang tidak berpengetahuan (janman ajnana atau janman avidya), dan sebagainya mengenai karakter gemar menolong yang bisa dilakukan oleh sadharma kepada yang memerlukan pertolongan yang wajar sesuai kondisinya di masyarakat.

\subsubsection{Karakter Suka Bercocok Tanam}

Keberadaan manusia tidak bisa dilepaskan dengan lingkungan yang ada di sekitar kehidupan bersama dalam bermasyarakat. Segenap lapisan warga masyarakat termasuk sadharma agar memiliki karakter suka bercocok tanam. Karakter suka bercocok tanam, misalnya : 1) menanam bunga (puspa) di area pura, 2) menanam buah-buahan (phalam) di area ladang, 3) menanam sayur-mayur (sabji) di area ladang, 4) menanam obatobatan (tamba) di area pekarangan, 5) menanam sirih di area pekarangan, 6) menanam padi di area sawah, 7) menanam tebu di area lahan ladang, 8) menanam tanaman biji-bijian (sarwa vija) di area ladang, 9) menanam umbi-umbian (sarwa bungkah) di area ladang, 10) menanam tanaman pelawa (patram) di area pura, 11) menanam tanaman ramuan obat (usadha) di area pekarangan, 12) menanam jenis kelapa (kalapa) di area 
ladang, 13) menanam tanaman bambu di area ladang, 14) menanam tanaman pinang di area ladang, 15) menanam tanaman andong di area pekarangan, dan menanam jenis tanaman lainnya yang sangat dibutuhkan untuk hidup dan kehidupan secara rutin.

\subsubsection{Karakter Berdisiplin}

Dalam kondisi di masyarakat bahwa karakter berdisiplin masih memerlukan perhatian sungguh-sungguh dari berbagai pihak untuk memberikan upaya positif untuk memantapkannya. Termasuk juga dalam dunia pendidikan yang ada diperankan oleh tenaga pendidikan dan tenaga kependidikan. Karakter berdisplin sangat penting bagi kehidupan kebersamaan dalam bermasyarakat, terlebih bagi tenaga guru agama Hindu untuk selalu membangun karakter berdisiplin di antaranya : 1) karakter berdisiplin beragama sesuai ajaran agama masing-masing, 2) karakter berdisiplin berlalu lintas, 3) karakter berdisiplin berbicara di tempat umum, 4) karakter berdisiplin bertindak, 5) karakter berdisiplin berpakaian, 6) karakter berdisiplin bekerja di kantor, 7) karakter berdisiplin memberikan pelayanan publik, 8) karakter berdisiplin mengelola anggran pemerintah, 9) karakter berdisiplin mengajar, 10) karakter berdisiplin melakukan penelitian, 11) karakter berdisiplin menuntun peserta didik, 12) karakter berdisiplin menerima tamu, 13) karakter berdisiplin memberikan keterangan pers, 14) karakter berdisiplin berjualan, 15) karakter berdisiplin membimbing peserta didik, 16) karakter berdisiplin dalam menerapkan peraturan pemerintah, 17) karakter berdisiplin dalam memutuskan perkara, dan sebagainya ada banyak hal yang memerlukan upaya disiplin dengan baik terhadap pihak lainnya.

\subsubsection{Karakter Keramahtamahan}

Mengenai karakter keramahtamahan merupakan hal yang utama bagi pergaulan hidup umat manusia dimanapun berada. Karakter keramahtamahan juga merupakan cirri khas dari seseorang ataupun sekelompok orang yang terlihat pada saat melakukan aksi maupun reaksi terhadap pihak lain dalam kebersamaan dan kebinekaan. Berkaitan dengan karakter keramahtamanan, antara lain : 1) karakter keramahtamanan dalam membimbing peserta didik atau sisya, 2) karakter keramahtamanan dalam menjelaskan materi pelajaran atau adhyayanam, 3) karakter keramahtamanan dalam memberikan contoh yang baik atau suabhyasa kepada peserta didik, 4) karakter keramahtamanan dalam menerima tamu atau atithi, 5) karakter keramahtamanan dalam melayani orang yang sakit, 6) karakter keramahtamanan dalam melayani orang tua, 7) karakter keramahtamanan dalam mengasuh anak yang kecil atau sisu, 8) karakter keramahtamanan dalam bergaul dengan tetangga, 9) karakter keramahtamanan dalam berkomunikasi dengan orang yang belum dikenal, 10) karakter keramahtamanan dalam mengemukakan pendapat saat rapat atau sabha, 11) karakter keramahtamanan dalam 
berbicara dengan orang suci atau sulinggih, dan sebagainya wujud dari karakter keramahtamahan guna dapat menjaga hubungan yang baik, sopan, santun dan terkesan ada tata susila atau tata krama.

\subsubsection{Karakter Cinta Damai}

Karakter cinta damai dalam kondisi bermasyarakat sangat penting diwujudkan dengan baik dan harmonis. Karakter cinta damai perlu ditumbuhkan terus secara kebersamaan, antara lain : 1) karakter cinta damai dengan saudara, 2) karakter cinta damai dengan orang tua, 3) karakter cinta damai dengan seluruh anggota keluarga, 4) karakter cinta damai dengan tetangga, 5) karakter cinta damai dengan warga satu kampung atau warga desa, 6) karakter cinta damai dengan warga di lingkungan tempat kerja, 7) karakter cinta damai dengan di lingkungan sekolah atau kampus, 8) karakter cinta damai dengan antar agama, 9) karakter cinta damai dengan antar suku, 10) karakter cinta damai dengan antar golongan atau kelompok masyarakat, 11) karakter cinta damai dengan sesama warga negara republik Indonesia, dan sebagainya yang terkait dengan wujud rasa perdamaian bagi internal dan eksternal dalam bermasyarakat, berbangsa, bernegara, agar terwujud hidup rukun, harmonis, nyaman, dan tenteram secara bersamasama.

\subsubsection{Karakter Peduli Lingkungan}

Berkenaan dengan karakter peduli lingkungan, maka hal ini merupakan model perilaku warga masyarakat terhadap kondisi lingkungan yang ada di sekitarnya. Lingkungan perlu menjadi perhartian secara baik dan penuh komitmen dimanapun manusia itu berada. Karakter peduli lingkungan misalnya : 1) karakter peduli lingkungan yang indah, 2) karakter peduli lingkungan yang bersih, 3) karakter peduli lingkungan yang sehat, 4) karakter peduli lingkungan yang apik, 5) karakter peduli lingkungan yang aman, 6) karakter peduli lingkungan yang tertib, 7) karakter peduli lingkungan yang hijau, 8) karakter peduli lingkungan yang lestari, 9) karakter peduli lingkungan yang menyenangkan, 10) karakter peduli lingkungan yang nyaman, 11) karakter peduli lingkungan yang inspiratif, dan sebagainya.

\subsubsection{Karakter Setia Kebangsaan}

Mengenai karakter cinta kebangsaan dapat diwujudkan dengan kepribadian baik tehadap bangsa dan negara Indonesia, seperti : 1) taat sebagai WNI, 2) taat terhadap peraturan pemerintah, 3) menjaga keutuhan NKRI, 4) taat dengan landasan Pancasila, 5) taat dengan UUD 1945, 6) taat terhadap keberagaman atau kebhinekaan, 7) taat sebagai WNI untuk membayar pajak, 8) taat sebagai WNI untuk membela kebenaran, 9) taat sebagai WNI untuk setia berbahasa Indonesia, 11) taat sebagai WNI untuk setia menghormati antar suku, 12) taat sebagai WNI untuk hidup dalam suasana persatuan, 13) taat sebagai WNI untuk berdemokrasi yang sehat, 14) taat sebagai WNI untuk menjadi warga panutan baik bagi bangsa dan negara Indonesia, 15) taat sebagai 
WNI untuk bertanggungjawab terhadap keberlanjutan pembangunan yang diprogramkan oleh pemerintah Republik Indonesia, dan lainnya sebagai wujud rasa setia dan taat sebagai WNI.

\subsubsection{Karakter Bela Negara}

Terkait dengan karakter bela negara antara lain : 1) menjaga persatuan dan kesatuan berbangsa, 2) menjaga persatuan dan kesatuan bernegara, 3) menjaga persatuan dan kesatuan NKRI, 4) menjaga dan membela tanah air Indonesia, 5) menjaga dan memelihara bendera merah putih, 6) menjaga dan memelihara bahasa persatuan bahasa Indonesia, 7) menjaga keutuhan seni, budaya, adat, dan perabadaban bangsa Indonesia, 8) menjaga dan memelihara suasana kerukunan dan kedamaian bangsa Indonesia, 9) menjaga negara Indonesia dari gangguan pihak yang tidak bertanggungjawab, 10) menjaga persatuan dan kesatuan bangsa Indonesia sampai kapanpun, 11) menjaga kekompakan, kerukunan, kedamaian, dan keutuhan NKRI, dan sebagainya.

\subsection{Karakter Pancasilais Nusantara}

Paparan pada sub ini mengenai karakter Pancasilais Nusantara melupti tentang : pertama, karakter Sraddha dan Bhakti kepada Ida Sang Hyang Widhi Wasa, kedua, karakter cinta, kasih, dan sayang sesama, ketiga, karakter solidaritas dalam kebersamaan, keempat, karakter bergaul yang sehat dan kompak, dan kelima, karakter mewujudkan sejahtra berkeadilan. Segenap umat Hindu atau sadharma agar memahami dan menerapkan kepribadian yang sesuatu dengan nilai luhur Pancasila di jagat nusantara tercinta. Umat Hindu termasuk para guru agama Hindu memiliki kewajiban mulia untuk menanamkan nilai luhur Pancasila kepada segenap lapisan masyarakat Hindu terlebih kepada para peserta didik di lingkungan sekolah masing-masing. Para guru agama Hindu memiliki tugas luhur untuk mengembangkan dan menumbuhkan jiwa semangat Pancasila dan selanjutnya untuk menghayati maupun mengamalkannya dalam kehidupan nyata sehari-hari maupun dalam kehidupan bersama di lingkungannya masing-masing secara rutin dan berkelanjutan. Harapannya agar umat Hindu selalu patuh dan taat pada eksistensi Pancasila sebagai landasan ideal di Negara Kesatuan Republik Indonesia tercinta.

"Rumusan lima nilai dasar sebagaimana tercantum dalam pembukaan Undang-Undang Dasar Negara Republik Indonesia Tahun 1945 adalah : 1. Ketuhanan Yang Maha Esa. 2. Kemanusiaan yang adil dan beradab. 3. Persatuan Indonesia. 4. Kerakyatan yang dipimpin oleh hikmat kebijaksanaan dalam permusyawaratan/perwakilan. 5 . Keadilan social bagi seluruh rakyat Indonesia" (Tim Kerja, 2012 : 44). Nilainilai luhur dalam rumusan Pancasila sebagaimana kutipan di atas sangat mulia dan penting untuk dihayati dan diamalkan dalam hidup kebersamaan di tengahtengah masyarakat. Semua komponen masyarakat memiliki kewajiban untuk memperteguh nilai-nilai luhur Pancasila di era kekinian sampai tetap menjadi 
landasan yang kuat dan kokoh sampai di masa mendatang. Menjaga dan mengamankan keutuhan nilai luhur pada Pancasila merupakan tanggungjawab bersama dari seluruh rakyat Indonesia.

2.3.1 Karakter Sraddha dan Bhakti kepada Ida Sang Hyang Widhi Wasa

Mengenai karakter Sraddha dan Bhakti kepada Ida Sang Hyang Widhi Wasa (Ranying Hatalla Langit) atau Tuhan Yang Maha Esa, maka dapat diuraikan beberapa karakter, antara lain : 1) umat Hindu agar selalu percaya (Sraddha) Ida Sang Hyang Widhi Wasa, 2) umat Hindu agar selalu melakukan sembah (Bhakti) kepada Ida Sang Hyang Widhi Wasa, 3) umat Hindu agar menjauhi atau menghindari sikap anti Ketuhanan Yang Maha Esa, 4) umat Hindu agar tidak bersikap anti agama Hindu dan juga tidak bersikap anti terhadap agama umat yang lainnya, 5) umat Hindu agar selalu menjunjung tinggi sikap toleransi (Tattwamasi) kepada semua umat beragama di Indonesia, 6) umat Hindu agar selalu saling hormat-menghormati dengan sesama umat secara internal dan dengan sesama umat beragama secara eksternal, 7) umat Hindu agar selalu taat melakukan persembahyangan sesuai ajaran agama Hindu sesuai pustaka suci Weda, 8) umat Hindu agar selalu mewujudkan kerukunan intern umat beragama, kerukunan antar umat beragama dan kerukunan antar umat beragama dengan pemerintah, dan sebagainya nilai luhur tentang Pancasilais. Nilai luhur Pancasila telah terbukti memberikan manfaat kebaikan buat semua dan telah memberikan dampak untuk mempersatukan semua umat beragama di Indonesia.

"Sila Ketuhanan Yang Maha Esa dalam Pancasila pada prinsipnya menegaskan bahwa bangsa Indonesia dan setiap warga negara harus mengakui adanya Tuhan. Oleh karena itu, setiap orang dapat menyembah Tuhan-nya sesuai dengan keyakinannya masingmasing. Segenap rakyat Indonesia mengamalkan dan menjalankan agamanya dengan cara yang berkeadaban yaitu hormaty menghormati satu sama lainnya. Negara menjamin kemerdekaan tiap-tiap penduduk untuk memeluk agamaanya masing-masing dan untuk beribadat menurut agamanya dan kepercayaan. Negara Indonesia adalah satu negara yang ber-Tuhan." (Tim Kerja, 2012 : 45). Sangat jelas sekali bahwa karakter sraddha atau percaya dan bhakti atau pengabdian kepada Tuhan Yang Maha Esa menjadi kewajiban bagi umat Hindu Indonesia.

\subsubsection{Karakter Cinta, Kasih, dan} Sayang Sesama

Dalam hal untuk mewujudkan suasana kebersamaan dengan sesama umat Hindu dan dengan semua umat beragama yang ada di Indonesia, maka uraian mengenai karakter cinta, kasih dan sayang sesama dapat diuraikan beberapa karakter, antara lain : 1) umat Hindu agar menyintai sesama umat beragama, 2) umat Hindu agar mengasihi sesama umat beragama, 3) umat Hindu agar menyayangi sesama umat beragama, 4) 
umat Hindu agar saling tolong menolong dengan sesama umat beragama, 5) umat Hindu agar meneguhkan perilaku toleransi dengan semua umat beragama, 6) umat Hindu agar tidak menistakan umat sendiri dan tidak menistakan umat beragama yang lainnya, 7) umat Hindu agar selalu menjaga persatuan, kesatuan, kerukunan, kedamaian, dan keharmonisan dengan sesama manusia di jagat raya, dan sebagainya.

"Sila kemanusiaan yang adil dan beradab dalam Pancasila pada prinsipnya menegaskan bahwa kita memiliki Indonesia Merdeka yang berada pula lingkungan kekeluargaan bangsa-bangsa. Prinsip Internasionalisme dan kebangsaan Indonesia adalah Internasionalisme yang berakar di dalam buminya Nasionalisme dan Nasionalisme yang hidup dalam taman sarinya Internasionalisme. Bahwa, akan dihargai dan dijunjung tinggi hakhak asasi manusia" (Tim Kerja, 2012 : 51). Nilai luhur sila kemanusiaan yang adil dan beradab sebagai nilai yang mempersatukan lapisan umat manusia di tingkat nasional dan mendapatkan pengakuan yang dijunjng tinggi secara hak asasi di tingkat interasional atau di level negara-negara di dunia.

\subsubsection{Karakter Solidaritas Dalam Kebersamaan}

Mengenai karakter solidaritas dalam kebersamaan maka dalam paparan ini diuraikan beberapa karakter : 1) seluruh umat Hindu agar bersatu untuk menegakkan kebenaran (dharma), 2) seluruh umat Hindu agar selalu bersatu dengan seluruh warga negara Indonesia,
3) seluruh umat Hindu bersatu untuk berbhakti kepada Negara Kesatuan Republik Indonesia, 4) seluruh umat Hindu agar bersatu untuk membela tanah air Indonesia tercinta, 5) seluruh umat Hindu bersatu untuk menolak segala bentuk sikap provokasi yang ingin memecah belah persatuan rakyat Indonesia, 6) seluruh umat Hindu agar bersatu untuk saling bahu membahu melakukan gotong royong, dan 7) seluruh umat Hindu agar bersatu untuk menghormati perbedaan agama, kepercayaan, suku, budaya, adat-istiadat, ras, golongan, bahasa, dan perbedaan profesi.

"Sila Persatuan Indonesia (Kebangsaan Indonesia) dalam Pancasila pada prinsipnya menegaskan bahwa bangsa Indonesia merupakan Negara Kebangsaan. Bangsa yang memiliki kehendak untuk bersatu, memiliki persatuan perangai karena persatuan nasib, bangsa yang terikat pada tanah airnya. Bangsa yang akan tetap terjaga dari kemungkinan mempunyai sifat chauvinistic. Persatuan berasal dari kata satu, yang berarti utuh tidak terpecahpecah. Persatuan juga menyiratkan arti adanya keragaman, dalam pengertian bersatunya bermacam corak yang beraneka ragam menjadi satu kebulatan. Persatuan Indonesia dalam sila ketigha ini mencakup persatuan dalam arti ideology, politik, ekonomi, sosial budaya, dan keamanan" (Tim Kerja, 2012 : 63). Dapat dipahami dengan jelas bahwa persatuan mengandung makna untuk persatuan segala aspek kehidupan masyarakat 
Indonesia yang memiliki luas wilayah dari Sabang--Merauke.

\subsubsection{Karakter Bergaul Sehat dan Kompak}

Suatu karakter yang penting bagi umat Hindu adalah adanya karakter bergaul sehat dan kompak. Adapun wujud karakter bergaul sehat dan kompak, meliputi : 1) umat Hindu agar saling menghargai perbedaan pendapat; 2) umat Hindu agar saling menghormati dalam bermusyawarah, 3) umat Hindu agar saling menjunjung tinggi nilai kebersamaan, 4) umat Hindu agar saling bersatu padu dalam mewujudkan cara musyawarah, 5) umat Hindu agar saling menghargai keputusan bersama, 6) umat Hindu agar saling melengkapi satu sama lainnya dalam kehidupan kebersamaan, 7) umat Hindu agar saling berbagi dalam bermusyawarah menuju mufakat, 8) umat Hindu agar saling maaf memaafkan dengan sesama warga masyarakat dalam kondisi yang berbeda-beda dalam kebersamaan, 9) umat Hindu agar saling menjunjung tinggi nilai dan martabat hidup kebersamaan, 10) umat Hindu agar saling bersinergi dengan semua unsur tokoh masyarakat yang ada dalam masyarakat majemuk, dan 11) umat Hindu agar saling menerima dan memberikan sumbangan pikiran positif dalam bermusyawarah menuju kesepakatan yang terbaik, dan sebagainya wujud karakter bergaul sehat dan kompak.

"Sila Kerakyatan yang Dipimpin

oleh Hikmah Kebijaksanaan dalam Permusyawaratan/ Perwakilan (mufakat atau demokrasi) dalam Pancasila pada prinsipnya menegaskan bahwa bangsa Indonesia akan terus memelihara dan mengembangkan semangat bermusyawarah untuk mencapai mufakat dalam perwakilan. Bangsa Indonesia akan tetap memelihara dan mengembangkan kehidupan demokrasi. Bangsa Indonesia akan memelihara serta mengembangkan kearifan dan kebijaksanaan dalam bermusyawarah" (Tim Kerja, 2012 : 6768). Sesuai makna pada sila keempat tersebut maka dapat dipahami bahwa rakyat Indonesia tetap dalam tatanan hidup bermusyawarah, berdemokrasi, dan bermufakat. Hidup saling berdampingan dalam suasana musyawarah yang sehat dan bijaksana yang didukung oleh kearifan lokal daerah.

\subsubsection{Karakter Mewujudkan Sejahtra Berkeadilan}

Terkait dengan karakter untuk mewujudkan sejahtra berkeadilan, maka dalam paparan ini diuraikan beberapa karakter, misalnya : 1) mewujudkan hidup sejahtra buat semuanya, 2) mewujudkan hidup sejahtra menuju kebaikan bersama, 3) mewujudkan hidup sejahtra bagi semua lapisan masyarakat, 4) mewujudkan hidup sejahtra secara lahir dan batin, 5) mewujudkan hidup sejahtra tanpa ada sikap diskriminasi, 6) mewujudkan hidup sejahtra menuju keberhasilan melalui mengenyam pendidikan secara merata, 7) mewujudkan hidup sejahtra dan bahagia bagi masyarakat yang di kota dan sampai ke masyarakat pedesaan, dan sebagainya 
tentang karakter kesejahtraan yang bekeadilan bagi seluruh rakyat Indonesia.

"Sila Keadilan Sosial bagi seluruh rakyat Indonesia (Kesejahtraan) dalam Pancasila pada prinsipnya menegaskan bahwa seyogyanya tidak aka nada kemiskinan dalam Indonesia Merdeka. Bangsa Indonesia bukan hanya memiliki demokrasi politik, tetapi juga demokrasi ekonomi. Indonesia harus memiliki keadilan politik dan keadilan ekonomi sekaligus. Indonesia harus memiliki kehidupan yang adil dan makmur bagi seluruh raktyat Indonesia" (Tim Kerja, 2012 : 78). Dalam hal ini bahwa keaddilan yang dimaksudkan adalah keadilan secara menyeluruh yang dimiliki oleh segenap rakyat Indonesia. Adil dalam hal ekonomi, adil secara demokrasi, adil secara hukum, adil dalam tercapainya kesejahtraan, dan sebagainya.

\section{PENUTUP}

Bangsa Indonesia sungguh subur dan makmur. Wilayahnya sangat luas dan kaya berbagai potensi alamnya. Penduduknya menganut beragam agama, ada yang beragama Islam, ada yang beragama Kristen, ada yang beragama Katolik, ada yang beragama yang beragama Hindu, ada yang beragama Buddha, dan ada yang beragama Konghuchu. Umat Hindu ada tersebar di seluruh Indonesia. ada berprofesi sebagai petani, pedagang, buruh, ABRI, Polri, PNS, ada sebagai dosen dan ada juga sebagai guru agama Hindu. Umat Hindu yang berprofesi guru agama Hindu memiliki tugas mulia dan luhur untuk membangun sumber daya manusia Hindu yang berkualitas melalui pendidikan karakter. Pribadi mulia dan luhur para kader Hindu terlahir dari tugas mulia yang dilakukan oleh para guru agama Hindu sebagaimana diupayakan oleh pemerintah untuk memberikan orientasi materi pendidikan karakter guna mencetak kader Hindu handal, kompetitif, kompetensi, bertanggungjawab, dan siap mengabdi kepada bangsa Indonesia.

Pendidikan karakter kepada para guru agama Hindu sesungguhnya upaya pembangunan di bidang nonfisik. Perlunya penyeimbangan antara pembangunan fisik dan nonfisik secara berkelanjutan sampai ke masa depan. Selain pendidikan karakter juga penting diteguhkan mengenai materi Pancasila, agar kehidupan bangsa Indonesia mencapai hidup yang sejahtra, bahagia, dan berkeadilan. Membangun nilai-nnilai karakter sesuai filsafat Hindu dan sekaligus menanamkian nuilai luhur Pancasila sebagai upaya positif guna menjadikan para guru agama Hindu sebagai pelopor dan pengabdi yang akan melahirkan generasi Hindu yang berkualitas, bertanggungjawab, dan memiliki ketahanan mental, moral spiritual, dan kepribadian yang mantap. Pendidikan karakter sesuai filsafat Hindu dimaksudkan untuk membangun kecintaan, ketulusan, kesetiaan, dan kesinambungan dedikasi dan loyalitas umat Hindu kepada agama Hindu sekaligus juga loyalitas kedapa bangsa dan Negara Kesatuan Republik Indonesia tercinta yang telah dibingkai dengan empat pilar kehidupan berngsa dan 
bernegara yakni Pancasila, UUD 1945, NKRI dan Bhinneka Tunggal Ika.

\section{DAFTAR PUSTAKA}

A. Isna, Nurla. 2014. Mencetak Karakter Anak Sejak Janin. Jogjakarta : Diva Press.

Ali, Muhammad. 1992. Guru Dalam Proses Belajar Mengajar. Bandung : Sinar Baru.

Koesoema, Doni. 2015. Pendidikan Karakter Strategi Mendidik Anak di Zaman Global. Jakarta : Grasindo.

Lickona, Thomas. 2013. Mendidik Untuk Membentuk Karakter. Jakarta : Bumi Aksara.

Mulyasa, H.E. 2014. Manajemen Pendidikan Karakter. Jakarta : Bumi Aksara.

Muslich, Masnur. 2014. Pendidikan Karakter Menjawab Tantangan Krisis Multidimensional. Jakarta : Bumi Aksara.

Sagala, H. Syaiful. 2009. Kemampuan Profesional Guru dan Tenaga Kependidikan. Bandung : Alfabeta.

Santosa, Iman Budhi. 2008. Budi Pekerti Bangsa. Jogjakarta : Arti Bumi Intaran.

Singer. I Wayan. 2015. Pendidikan Karakter Berlandaskan Tri Kaya Parisudha. Denpasar : Pustaka Manik Geni.

Soemanto, Wasty. 1998. Psikologi Pendidikan Landasan Kerja Pemimpin Pendidikan. Jakarta : Rineka Cipta.
Subagiasta, I Ketut. 2012. Praktek Agama Hindu. Denpasar : Bali Post.

Subagiasta, I Ketut. 2014. Renungan Filsafat Hindu. Surabaya : Paramita.

Subagiasta, I Ketut. 2015. Renungan Filsafat Hindu Jilid II. Surabaya : Paramita

Subagiasta, I Ketut. 2015. Filosofi Simbol di Basarang Kalimantan Tengah. Surabaya : Paramita.

Subagiasta, I Ketut. 2016. Filosofi Karakter Hindu Konsep Kepemimpinan Dalam Hindu. Tangerang : LDD.

Subagiasta, I Ketut. 2017. Filosofi Simbol-Simbol Keagamaan Hindu Dalam Kehidupan Beragama Hindu di Kota Palangka Raya. Tangerang : LDD.

Tim Kerja. 2012. "Empat Pilar Kehidupan Berbangsa dan Bernegara". Diterbitkan oleh Sekretariat Jenderal MPR RI Jakarta.

Wiana, I Ketut. 2013. Weda Wakya IV : Weda Memperbaiki Prilaku dan Kebiasaan Hidup. Surabaya : Paramita.

Zubaedi. 2013. Dessain Pendidikan Karakter Konsepsi dan Aplikasinya Dalam Lembaga Pendidikan. Jakarta : Kencana Prenada Media Group.

Zuriah, Nurul. 2008. Pendidikan Moral \& Budi ekerti Dalam Perspektif Perubahan. Jakarta : Bumi Aksara. 